\title{
Establishing Brand Based Organization by Customer Perspective in Jungleland Adventure Theme Park, Sentul City, Bogor - Indonesia
}

\author{
Ahmad Hasyim, Angel Jessyca S.S, Fauzan Achmad H., Luki Wijaya, Nurul Komalasari, Restu Fitria \\ Maudy, Dr. Anang Sutono, CHE., Sumaryadi, MM. \\ Tourism Business Management Study Program, Bandung Institute of Tourism \\ Indonesia \\ timfpsjl.mbw12@gmail.com
}

\begin{abstract}
This research is conducted to formulate the program of Brand-Based Organization at Jungleland Adventure Theme Park. Research is carried out by identifying the visitor perceptions regarding the implementation of brand identity and professionalism implemented by Jungleland's human resources. This research is also conducted in-depth interview to the management and frontline staffs to get the facts and confirm the findings. In addition, it is to compare with competitors' brand identity to determine the brand position of Jungleland.

The result shows that Jungleland's brand identity represented by the symbol has the lowest value as perceived by visitors as compared with brand as a product and brand as a person. When Jungleland is compared with its competitors, Trans Studio Bandung, Taman Safari Bogor and Dunia Fantasi, it has the strong point righteously as the later entrant through the attributes of existing brands.

Regarding to the results, proposed recommendations for human resources development program towards brand-based organization includes the Talent Management Program and Rewards Management Program.
\end{abstract}

Keywords: Brand-based organization; Brand identity, Customer perspective, Human capital.

\section{INTRODUCTION}

Jungleland Adventure Theme Park is located at Sentul City, Bogor. Jungleland has 35 ha areas and divided into three zones and 35 rides enjoyed by visitors. Jungleland is managed by PT. Jungleland Asia under PT. Bakrieland Development, Tbk. It is the largest thematic park in Indonesia started to be operated on April 22, 2013.

As a business unit that is located in the strategic point towards the Bogor-Puncak-Cianjur, it has main competitors, Dunia Fantasi Ancol (Dufan), Taman Safari Indonesia Cisarua (TSI) and Trans Studio in Bandung (TSB).

Based on previous studies of the "Analysis of Business Positioning Jungleland" in 2014, Jungleland position is still below Dufan and TSI, but in terms of products and market, Jungleland can be competed with them.

Jungleland occupies a lower position than its competitors. Regarding to the period of the operation, Jungleland comes into the theme park business lately, but even as a later entrant, Jungleland can be a market leader through its product and market side. To have a competitiveness, the business unit must have an effective strategy.

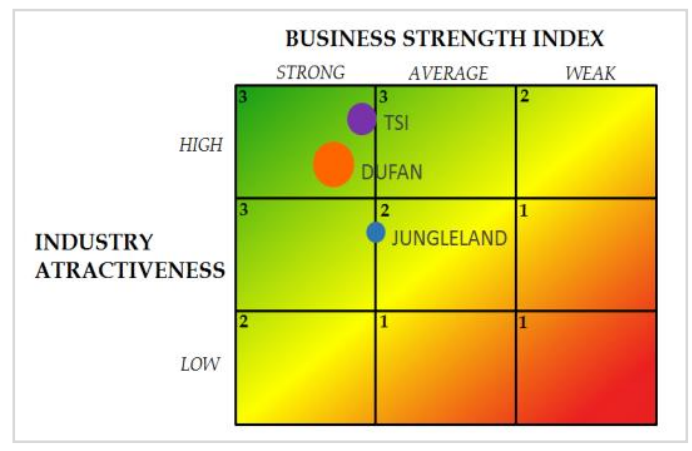

Fig.1. G.E. Matrix Jungleland Position Analysis 2014

Human capital is a differentiator for the organization and a core for forming competitiveness (competitive advantage). ${ }^{[1]}$ The success of the company in the market competition is determined by human capital, not physical capital, so companies have to invest in training to increase the resources of knowledge, skills and abilities of their employees intensively. ${ }^{[2]}$

Employee is the center of the process in building the brand, and their behavior can strengthen the brand value offered to the market.

\footnotetext{
${ }^{[1]}$ Marr, B. \& Jonathan Chatzkel, Intellectual Capital at The Crossroads: Managing, Measuring, and Reporting of IC, (Emerald Insight: Journal of Intellectual Capital, 2004), p.338.

${ }^{\text {[2] }}$ Preffer, Jo Competitive Advantage Through People: Unleashing The Power of The Workforce, (Boston: Harvard Business School Press, 1994), p.349
} 
If it is not consistent, it will ruin the credibility of the message being offered. Therefore, it is important to consider how the values and behavior of employees can be aligned with the desired brand value. ${ }^{[3]}$ Moreover, all Jungleland employees have an important role in marketing activities by making all employees feel belonging to the company's brand and understanding their role in turning brand aspirations into reality through operational activities. To build a strong brand, employees must represent as the brand ambassador for the company through their engagement, connecting, and commitment to the company's brand.

Investment on human resources has an impact on competitiveness. Therefore, the need for strategic steps and implementable for Human Resources Development in Jungleland is to gain the conditions: (1) Clarity in decisions and execution, (2) Greater profits and returns, (3) Market share gains, (4) A lever for attracting the best employees, (5) Customer loyalty, which in turn drives repeated business, (6) Clear, valued, and sustainable differentiation from competition, and (7) A more forgiving marketplace when mistakes are made. ${ }^{[4]}$

With this awareness, it is important for management to develop the capacity of employees as assets to strengthen the Jungleland's brand identity.

\section{CONCEPT APPROACH}

Theme park is a set of experience in one location, enables everyone to run off with activities of fantasy, game, fair, restaurant and accommodation to give the customer total experience. $^{[5]}$

Human capital approach is related to the added value to the organization. Considering human capital concept, the role of human capital as differentiator to the organization and the core create competitive advantage. ${ }^{[1]}$ Human capital is the most important intangible asset to the organization, instead of copyright, customer relation, brand and image.

Brand is an asset needs to be managed. Investing in brand building needs to be done internally and externally, and improves brand advantage, brand asset value, and the value of a brand. ${ }^{[6]}$ The implementation of brand identity is divided into a process of internalization and externalization. The process of brand externalization is through the marketing communication program. Meanwhile, Brand internalization process is through internal communication to establish a brand-based organization. ${ }^{[7]}$

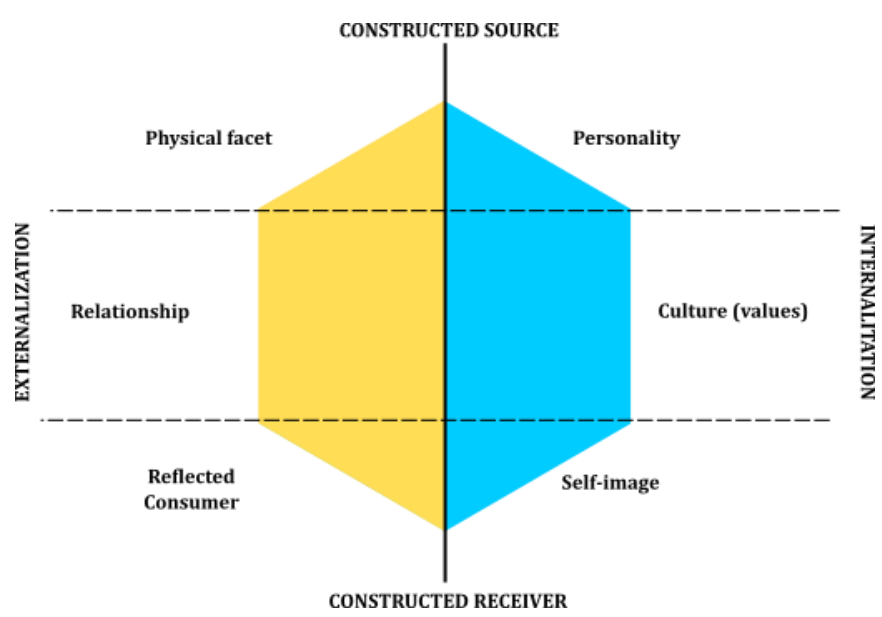

Fig 2. Brand Externalization and Internalization

This research focuses on brand-based organization (see blue colour in figure 2) as a follow-up of previous research Field Project Study 2014, the marketing communication in Jungleland Adventure Themepark.

Brand-based organization is the acceleration in the development of business organizations. Brandbased organization is gained with the brand report to the top of an organization to generate brand through the delivery efficiency of employees. ${ }^{[8]}$ Jungleland's employees are brand ambassadors or brand conveys to visitors on Jungleland.

Brand identity is a set of associations brand identity created or preserved hearts brand strategy development. The brand identity will help to establish a rapport between brand and customers to generate value proposition involves functional benefits, emotional, or self-expression. ${ }^{[9]}$

[3] Harris, Fiona and de Chernatony, Leslie, Corporate Branding and Corporate Brand Performance. (European Journal of Marketing:2001), p.442.

[4] Scott, M. Davis, Brand Asset Management, (California: Pearson Press, 2000), p.229-230.

[5] Sun, Lou-Hon \& Muzaffer Uysal, The Role of Theme Parks in Tourism, (Florida: FIU Digital Commons, 1994), p.72.

[6] Scott, M. Davis, Op.Cit., p.31.

[7] Kapferer, Jean-Noël, The New Strategic Brand Management: Creating and Sustaining Brand Equity Long Term, (USA: Kogan Page Publishers, 2007), p.105107.

[8] Scott, M. Davis, Op.Cit., p.231.

[9] Aaker, David A, Building Strong Brand. $2^{\text {nd }}$ Edition, (New York: Free Press, 1996), p.68 
If it is not consistent, it will ruin the credibility of the message being offered. Therefore, it is important to consider how the values and behavior of employees can be aligned with the desired brand value. ${ }^{[3]}$ Moreover, all Jungleland employees have an important role in marketing activities by making all employees feel belonging to the company's brand and understanding their role in turning brand aspirations into reality through operational activities. To build a strong brand, employees must represent as the brand ambassador for the company through their engagement, connecting, and commitment to the company's brand.

Investment on human resources has an impact on competitiveness. Therefore, the need for strategic steps and implementable for Human Resources Development in Jungleland is to gain the conditions: (1) Clarity in decisions and execution, (2) Greater profits and returns, (3) Market share gains, (4) A lever for attracting the best employees, (5) Customer loyalty, which in turn drives repeated business, (6) Clear, valued, and sustainable differentiation from competition, and (7) A more forgiving marketplace when mistakes are made. ${ }^{[4]}$

With this awareness, it is important for management to develop the capacity of employees as assets to strengthen the Jungleland's brand identity.

\section{CONCEPT APPROACH}

Theme park is a set of experience in one location, enables everyone to run off with activities of fantasy, game, fair, restaurant and accommodation to give the customer total experience. $^{[5]}$

Human capital approach is related to the added value to the organization. Considering human capital concept, the role of human capital as differentiator to the organization and the core create competitive advantage. ${ }^{[1]}$ Human capital is the most important intangible asset to the organization, instead of copyright, customer relation, brand and image.

Brand is an asset needs to be managed. Investing in brand building needs to be done internally and externally, and improves brand advantage, brand asset value, and the value of a brand. ${ }^{[6]}$ The implementation of brand identity is divided into a process of internalization and externalization. The process of brand externalization is through the marketing communication program. Meanwhile, Brand internalization process is through internal communication to establish a brand-based organization. ${ }^{[7]}$

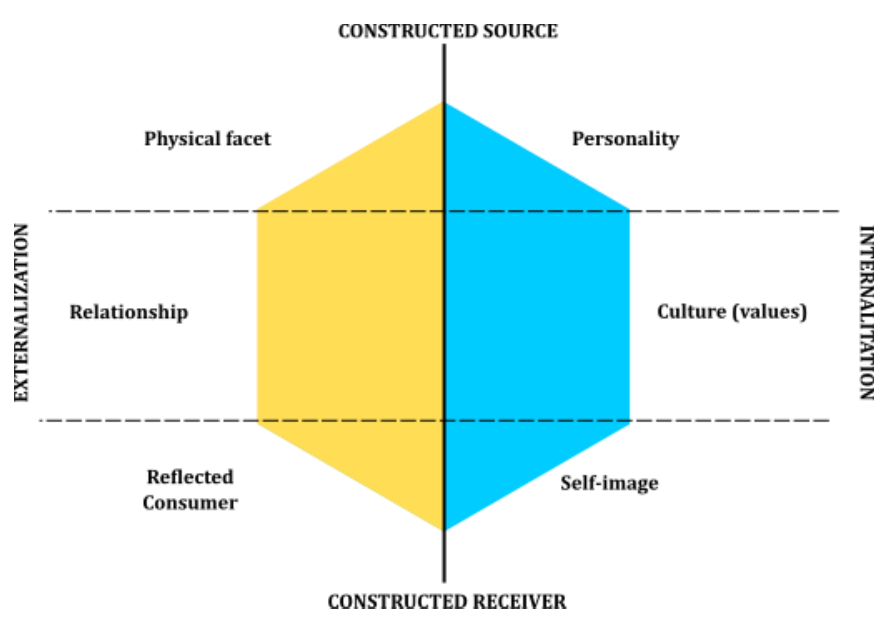

Fig 2. Brand Externalization and Internalization

This research focuses on brand-based organization (see blue colour in figure 2) as a follow-up of previous research Field Project Study 2014, the marketing communication in Jungleland Adventure Themepark.

Brand-based organization is the acceleration in the development of business organizations. Brandbased organization is gained with the brand report to the top of an organization to generate brand through the delivery efficiency of employees. ${ }^{[8]}$ Jungleland's employees are brand ambassadors or brand conveys to visitors on Jungleland.

Brand identity is a set of associations brand identity created or preserved hearts brand strategy development. The brand identity will help to establish a rapport between brand and customers to generate value proposition involves functional benefits, emotional, or self-expression. ${ }^{[9]}$

[3] Harris, Fiona and de Chernatony, Leslie, Corporate Branding and Corporate Brand Performance. (European Journal of Marketing:2001), p.442.

[4] Scott, M. Davis, Brand Asset Management, (California: Pearson Press, 2000), p.229-230.

[5] Sun, Lou-Hon \& Muzaffer Uysal, The Role of Theme Parks in Tourism, (Florida: FIU Digital Commons, 1994), p.72.

[6] Scott, M. Davis, Op.Cit., p.31.

[7] Kapferer, Jean-Noël, The New Strategic Brand Management: Creating and Sustaining Brand Equity Long Term, (USA: Kogan Page Publishers, 2007), p.105107.

[8] Scott, M. Davis, Op.Cit., p.231.

[9] Aaker, David A, Building Strong Brand. $2^{\text {nd }}$ Edition, (New York: Free Press, 1996), p.68 
Jungleland offers emotional benefits and better experience while playing rides in the jungle.

Brand identity consists of four elements, which can create a distinct identity. ${ }^{[10]}$

1. 'Brand as product' which the scope and attributes of products are considered to meet the visitors demand. Jungleland offers an experience through the zoning of games delivered through frontline employees.

2. 'Brand as organization' focuses on brand attributes to the organization rather than to the products, by subjective approach. It can be implemented in the form of internal communication program or delivering brand identity from management to employees.

3. 'Brand as person' can be embedded into personal Jungleland employees through the ability to serve the visitors. Jungleland brand identity can be conveyed indirectly through the employee's personality.

4. 'Brand as symbol' is the final element to focus on the visual aspects that can help to create an awareness and a brand recognition. Symbols in the application of Jungleland brand identity can be a mascot, sign, zoning and other visual attributes.

\section{METHODOLOGY}

This research uses a descriptive method with the qualitative and quantitative approach (combination). In conducting the data collection activities, both primary and secondary data, then the data collection techniques used are observation and debriefing through interviewing using research instruments such as interview, questionnaires and other research tools.

Primary data is obtained from a questionnaire from visitors, checklists and interview to the management and frontliner employees of Jungleland. The secondary data is obtained from the archive and documentation such as employee programs, organizational structure, and employee standards.

In finding at the relationship among variables, the analysis technique used is the gap analysis. In the opinion of a gap analysis is an analysis of the gap between your business needs, which is caused by various reasons. So it takes an effort to identify which parts it turns out may have a gap, because it is impossible to find $100 \%$ fit or perfect. $^{[11]}$

The analytical tool used in this study is the Pareto chart. Pareto chart is one type of chart consists of a bar graph and also the line describes the dominant gap to construct the most priority actions.

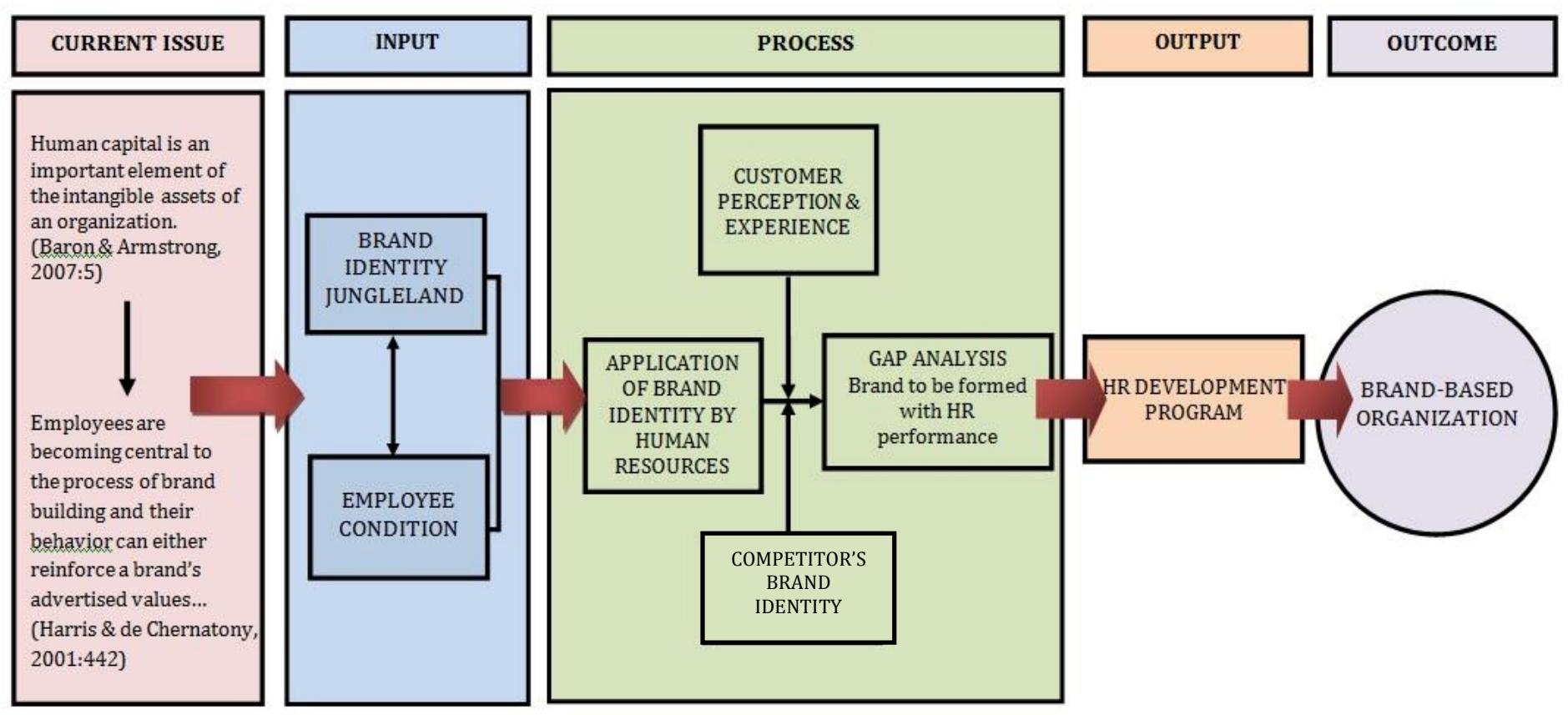

Fig.3. Research Framework

\footnotetext{
${ }^{[10]}$ Ibid, p.78

${ }^{[11]}$ Ray, Enterprise Resource Planning, (India: Tata McGraw-Hill Education, 2011), p.163.
} 


\section{FINDINGS}

\section{Market Profile}

The respondents of the male visitors are slightly more dominant than female visitors. The average life span of 31-40 (visit with their children) with income is less dominant than IDR2,500,000. Jungleland market is dominated by visitors from Jabodetabek (city with economic chain form capital of Indonesia, up to $63,7 \%$ ). Majority of Jungleland visitors visits with their family $(32,4 \%)$, corporate outing $(23,4 \%)$, visit with companion $(20,5 \%)$, with couple $(14,2 \%)$, school group $(9,2 \%)$ and by individual $(0,4 \%)$.

Meanwhile, most visitors spend money of IDR150,001 up to IDR200,000 per one person for food, drinks, souvenirs, game tickets, and so on except for the entrance ticket. Based on the number of visits, respondents visited for the first time is to $71 \%$, by $2^{\text {nd }}$ times $(22,4 \%), 3^{\text {rd }}$ times $(4,5 \%)$, and more than $5^{\text {th }}$ times $(0,8 \%)$.

\section{Jungleland Customer Perspective}

Our research indicates that Brand-Based Organization can be established by synchronized the brand internalization towards customer perspectives. There are four variables of brand identity used; Brand as symbol, brand as product, brand as person and brand as organization.

Four variables except the brand as an organization are modified to 22 indicators of questionnaire. Variable Brand as a Symbol scored 2,7 on the visitors with a gap of 1,24 on a perfect score of 4,00. Variable brand as a product scored 2,97 with a gap of 1,03 and variable brand as a person get the highest score among others, score 3,04 and smaller gap is 0,96 .

Furthermore, the indicator "I know the Jungleland mascot" gets the highest gap $(1,57)$ in the variable Brand as a symbol. Meanwhile, the indicator "Event Organizer by Jungleland is my reason to visit" gets the highest gap $(1,37 \%)$, and variable Brand as a Person gets the highest gap $(1,22)$ of the indicator "Call of employees makes me want to try the Jungleland rides".

\section{Competitors Brand Value}

The conditions of competition in the business of tourist attraction, Jungleland has quite a lot of competitors in the application of brand identity, both in terms of products and market, includes:
Taman Safari Indonesia, Dunia Fantasi, and Trans Studio Bandung. Trans Studio positioned itself as the largest indoor Theme Park in Southeast Asia,

Jungleland's brand essence is the concepts of "forest" in the theme park. While Trans Studio Bandung is "happiness" to visitors. Dunia Fantasi (Dufan) is the most powerful competitor which is older than Jungleland. In general, it can be said that Dufan has a stronger positioning compared to Jungleland. Trans Studio Bandung (TSB) as a business unit that has similarities with Jungleland rides needs to be considered as a strong competitor in the implementation of brand identity by employees.

In terms of demographics, Taman Safari Indonesia is competitor for Jungleland because both are located in the same district of Bogor. Currently, the TSI does not only offer attractions such as the zoo, but also has a leisure park.

\section{ANALYSIS}

In this section, it will conduct the analysis of implementation of Jungleland's brand identity by human resources, analysis of the application of brand as a symbol, product, and person. It is also discussed the brand identity comparison of the competitors.

\section{The Implementation of Brand as Symbol}

Analysis of the brand as symbol objective is to facilitate and accelerate the planting of Jungleland brand in the minds of visitors through the visualisation brand owned.

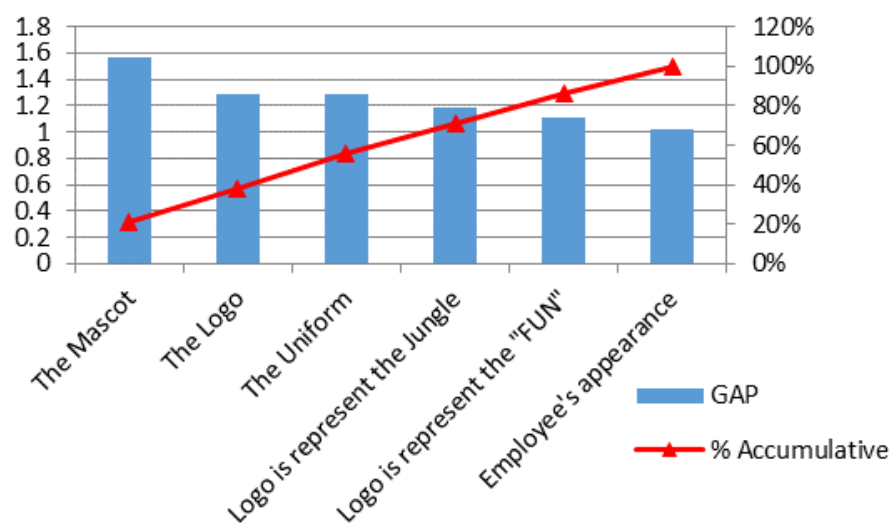

Fig. 4. Pareto Analysis of Brand as Symbol

The biggest gap has been found in statements about Jungleland mascot. Values obtained gap 1,57 is also the highest value of all statements submitted to the visitor, while visitors disagreed are $51.1 \%$. 
So Jungleland's mascot aspect needs to get more attention than other aspects.

The pareto chart shows that the Jungleland's mascot, will have an impact of $21 \%$ on the overall gap exists. The next gap, "The introduction of the logo", it can complete $38 \%$ of the total gap exists.

\section{The Implementation of Brand as Product}

Analysis of the brand as product goal is to facilitate and accelerate the implementation of Jungleland brand on the minds of visitors through the product scope, product attributes, and quality or value.

The biggest gap found in the statement is the Jungleland's event. Gap value obtained 1,37 shows that Jungleland's event aspect needs to get more attention than other aspects of the product, while visitors disagreed are $42.3 \%$. Then the Jungleland's event aspects need attention more than any other aspect in this variable.

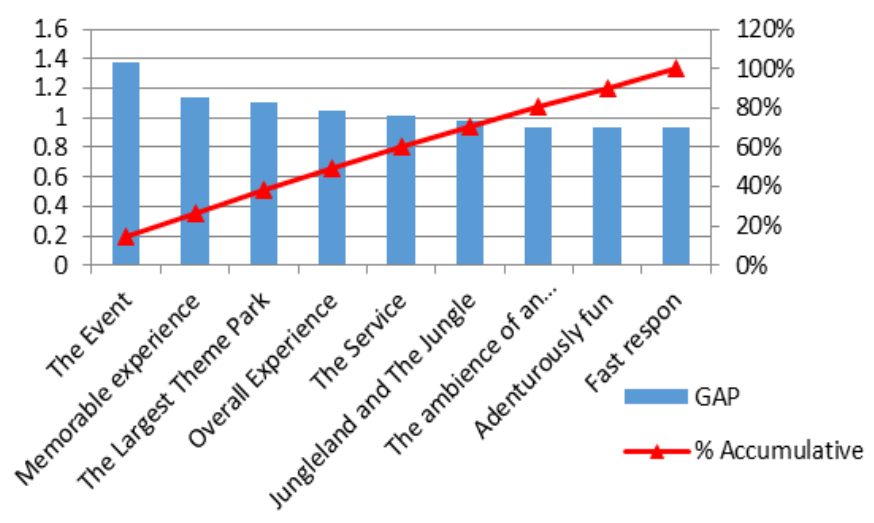

Fig. 5. Pareto Analysis of Brand as Product

Pareto chart above shows that, the gap regarding the event Jungleland will have an impact of $15 \%$ on the overall gap exists. The next gap, "a memorable experience", it can complete $27 \%$ of the total gap exists.

\section{The Implementation of Brand as Person}

Analysis of the brand as a person goal is to simplify and speed up the implementation of Jungleland's brand in the minds of visitors through personality of its employees.

The biggest gap found on statements is "Jungleland's employees invitation to visitors to play rides". Gap value obtained is 1,12 indicating that these aspects need to get attention from other aspects of the products, while visitors disagreed are $23.2 \%$. So the invitation aspect Jungleland employees need to get attention from other aspects of this variable.

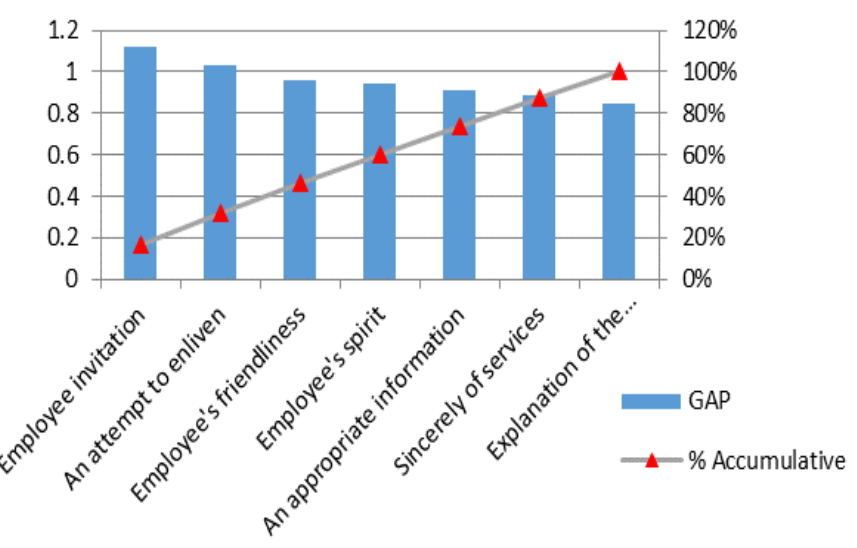

Fig. 6. Pareto Analysis of Brand as A Person

Pareto chart above shows that, the Jungleland's employee invitation to visitors, will have an impact of $17 \%$ on the overall gap exists. The next gap is "an attempt to enliven", it can complete $32 \%$ of the total gap exists.

\section{Brand Identity Comparison with Competitors}

The analysis of the competitor's brand identity Jungleland aims to know the general picture of Jungleland position compared to the competitors. Brand delivered to the visitor will shape perceptions the visitors itself. Each theme park has an identity distinguishes each with competitors. The identity makes visitors have different perceptions of each other theme park.

Jungleland is included as a new comer in the themepark industries compared with its competitors like Dufan, TSI, and TSB but it has opportunity to take a larger market.

In the next matrix, Jungleland shows the position of a strong brand identity that is not according to the perceptions of visitors. It is because the value positioning statement, brand promise, and brand essence are under 3,00. The brand personality or descriptions desired by the people of Jungleland consists of: Seru (Fun), Aman (Safe), Nyaman (Comfortable), Hutan (Forest), Fantasi (Fantasy), Penuh Kejutan (Full of Surprises) yet high perceived by visitors. 


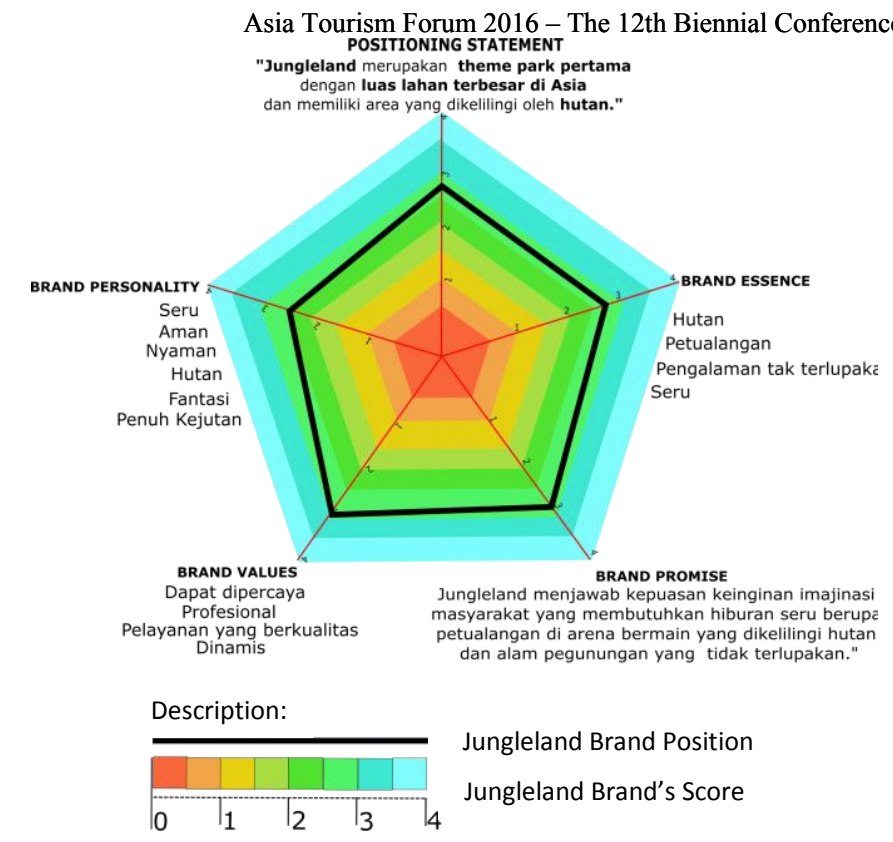

Fig. 7. Brand Identity Jungleland Matrix

Brand values are the values contained in a brand and a quality built and maintained by internal performance in Jungleland mainly through the frontliners. In the next matrix Jungleland's brand values are attributes of the brand identity perceived well by the visitors. It shows that the development of quality human resources is a Jungleland's priority in increasing Jungleland's brand identity on the minds of visitors.

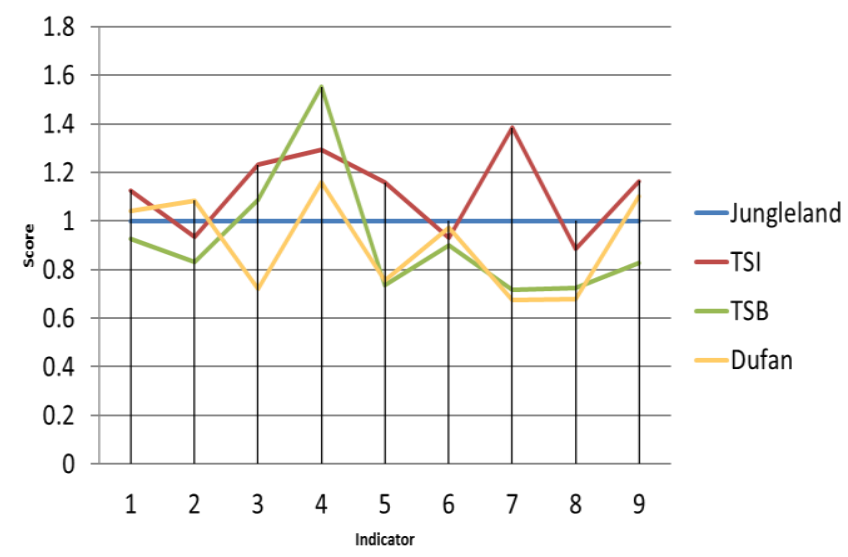

Fig. 8. Brand Identity Comparison with Competitors

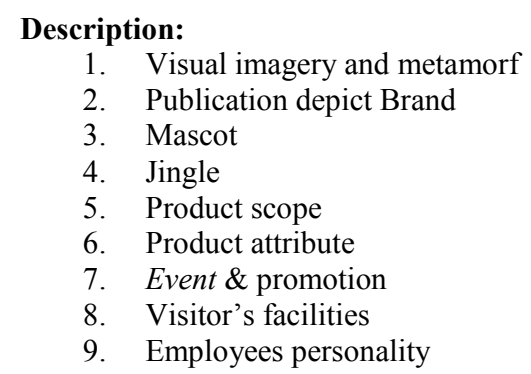

The higher the position of the curve (above 1) the more superior on Jungleland brand attributes of Hospitality and Tourism Industry in Asia (ATF-16)
than competitors and vice versa. From the above graphic, Jungleland compared TSI advantage of all the attributes are in terms of events and promos, Jungleland 0,38 ahead of the TSI. So Jungleland manages to deliver the brand through events and promos offered to visitors. When compared to the TSB and Dufan, Jungleland's advantage of all attributes is a brand through the delivery of superior jingle of 0,55 and 0,16 of the TSB of Dufan.

From all existing attributes, Jungleland's weakness compared to TSI, and Dufan obviously from the delivery of the brand through the existing facilities at the theme park. Jungleland is 0,12 lower than TSI and 0,32 of Dufan. And when it is compared with TSB, Jungleland's weaknesses are from the attributes of the delivery of the brand through events and promos, Jungleland is 0,28 lower thanTSB. Event and promos offered by TSB are still much more to convey the brand compared to Jungleland.

\section{CONCLUSION}

There is a gap among brand identities in customer's perspectives and the organization. The gap is from the brand internalization through top level management and the frontliner. Therefore, based on this research framework two programs are needed to establish the brand based organization in Jungleland Adventure Theme Park: Talent Management Program and Reward Management Program. The programs designed to improve four main aspects: attitude, skill, knowledge and Jungleland brand identity. Talent Management program has an initiative program such as Action Learning, Buzz Program, and Employee Mentoring. Reward Management has an initiative program, Reward, achievement and Most Valuable Employee.

\section{REFERENCES}

[1] Marr, B. \& Jonathan Chatzkel. 2004. Intellectual Capital At The Crossroads: Managing, Measuring, And Reporting Of IC: Journal Of Intellectual Capital.

[2] Preffer, J. 1994. Competitive Advantage Through People: Unleashing The Power of The Workforce. Boston, Mass., Harvard Business School Press.

[3] Harris, Fiona and De Chernatony, Leslie. 2001. Corporate Branding and Corporate Brand Performance. European Journal of Marketing. 
Asia Tourism Forum 2016 - The 12th Biennial Conference of Hospitality and Tourism Industry in Asia (ATF-16)

[4], [6] Scott, M. Davis. 2000. Brand Asset Management. California: Pearson Press.

[5] Sun, Lou-Hon \& Muzaffer Uysal. 1994. The Role of Theme Parks in Tourism. Florida: FIU Digital Commons.

[7] Kapferer, Jean-Noël. 2007. The New Strategic Brand Management: Creating and Sustaining Brand Equity Long Term. USA: Kogan Page Publishers.

[9], [10] Aaker, David A. 1996. Building Strong Brand. $2^{\text {nd }}$ Edition. New York: Free Press.

[11] Ray. 2011. Enterprise Resource Planning. India: Tata McGraw-Hill Education. 
Jungleland offers emotional benefits and better experience while playing rides in the jungle.

Brand identity consists of four elements, which can create a distinct identity. ${ }^{[10]}$

1. 'Brand as product' which the scope and attributes of products are considered to meet the visitors demand. Jungleland offers an experience through the zoning of games delivered through frontline employees.

2. 'Brand as organization' focuses on brand attributes to the organization rather than to the products, by subjective approach. It can be implemented in the form of internal communication program or delivering brand identity from management to employees.

3. 'Brand as person' can be embedded into personal Jungleland employees through the ability to serve the visitors. Jungleland brand identity can be conveyed indirectly through the employee's personality.

4. 'Brand as symbol' is the final element to focus on the visual aspects that can help to create an awareness and a brand recognition. Symbols in the application of Jungleland brand identity can be a mascot, sign, zoning and other visual attributes.

\section{METHODOLOGY}

This research uses a descriptive method with the qualitative and quantitative approach (combination). In conducting the data collection activities, both primary and secondary data, then the data collection techniques used are observation and debriefing through interviewing using research instruments such as interview, questionnaires and other research tools.

Primary data is obtained from a questionnaire from visitors, checklists and interview to the management and frontliner employees of Jungleland. The secondary data is obtained from the archive and documentation such as employee programs, organizational structure, and employee standards.

In finding at the relationship among variables, the analysis technique used is the gap analysis. In the opinion of a gap analysis is an analysis of the gap between your business needs, which is caused by various reasons. So it takes an effort to identify which parts it turns out may have a gap, because it is impossible to find $100 \%$ fit or perfect. $^{[11]}$

The analytical tool used in this study is the Pareto chart. Pareto chart is one type of chart consists of a bar graph and also the line describes the dominant gap to construct the most priority actions.

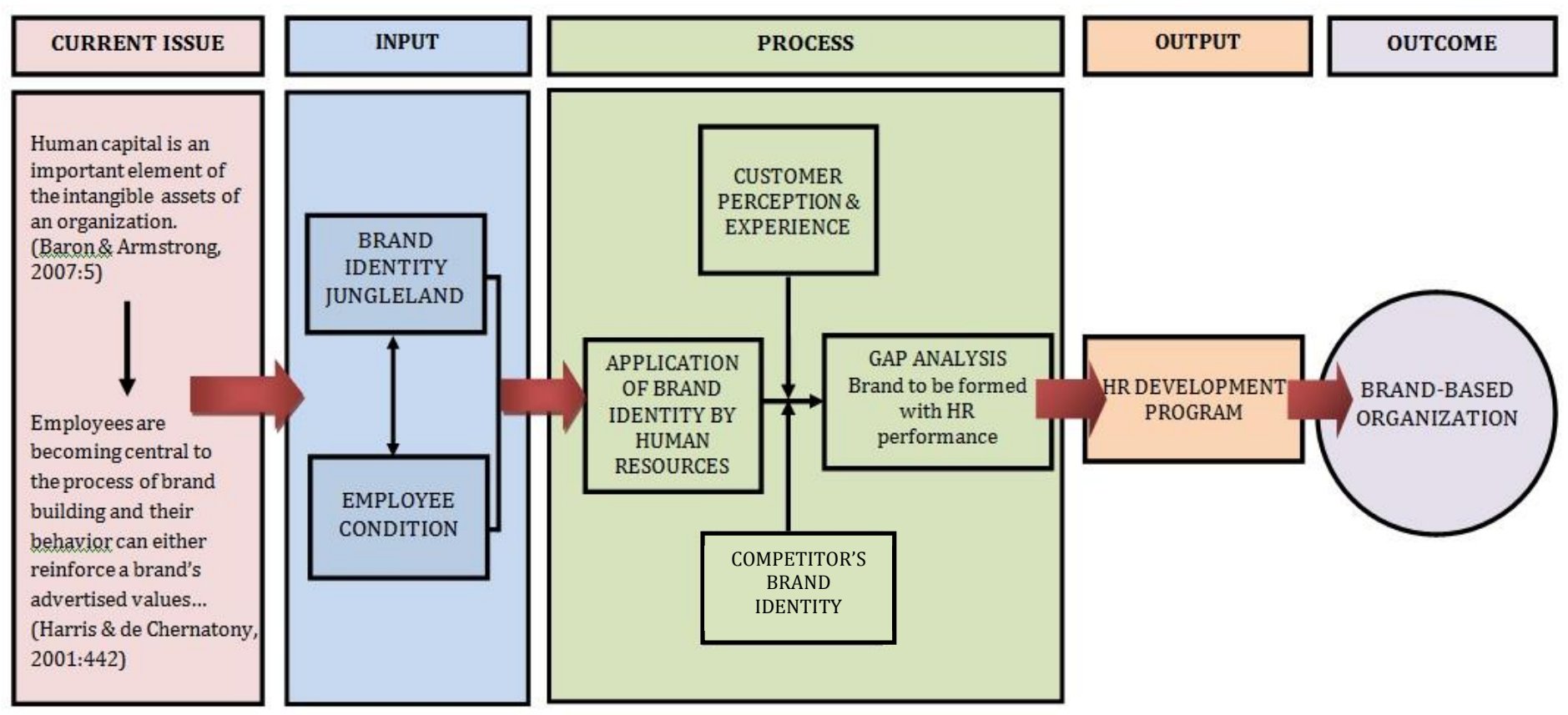

Fig.3. Research Framework

\footnotetext{
${ }^{[10]}$ Ibid, p.78

${ }^{[11]}$ Ray, Enterprise Resource Planning, (India: Tata McGraw-Hill Education, 2011), p.163.
} 
So Jungleland's mascot aspect needs to get more attention than other aspects.

The pareto chart shows that the Jungleland's mascot, will have an impact of $21 \%$ on the overall gap exists. The next gap, "The introduction of the logo", it can complete $38 \%$ of the total gap exists.

\section{The Implementation of Brand as Product}

Analysis of the brand as product goal is to facilitate and accelerate the implementation of Jungleland brand on the minds of visitors through the product scope, product attributes, and quality or value.

The biggest gap found in the statement is the Jungleland's event. Gap value obtained 1,37 shows that Jungleland's event aspect needs to get more attention than other aspects of the product, while visitors disagreed are $42.3 \%$. Then the Jungleland's event aspects need attention more than any other aspect in this variable.

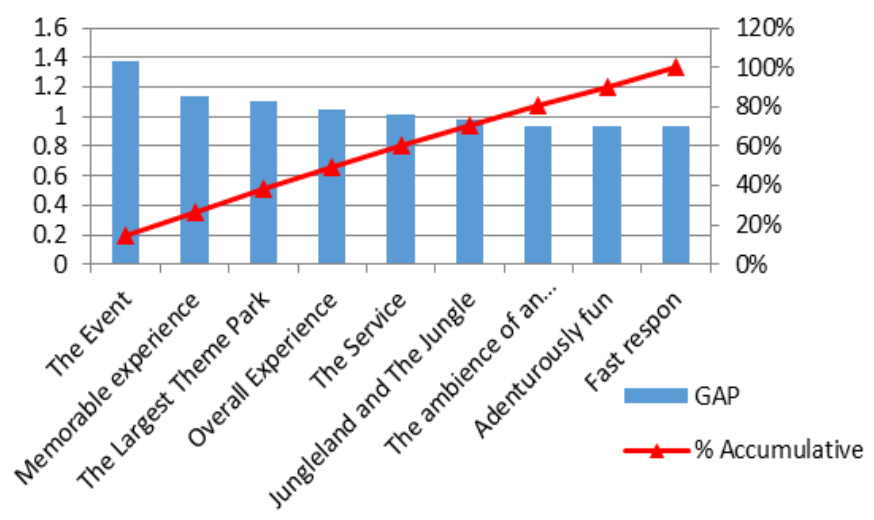

Fig. 5. Pareto Analysis of Brand as Product

Pareto chart above shows that, the gap regarding the event Jungleland will have an impact of $15 \%$ on the overall gap exists. The next gap, "a memorable experience", it can complete $27 \%$ of the total gap exists.

\section{The Implementation of Brand as Person}

Analysis of the brand as a person goal is to simplify and speed up the implementation of Jungleland's brand in the minds of visitors through personality of its employees.

The biggest gap found on statements is "Jungleland's employees invitation to visitors to play rides". Gap value obtained is 1,12 indicating that these aspects need to get attention from other aspects of the products, while visitors disagreed are $23.2 \%$. So the invitation aspect Jungleland employees need to get attention from other aspects of this variable.

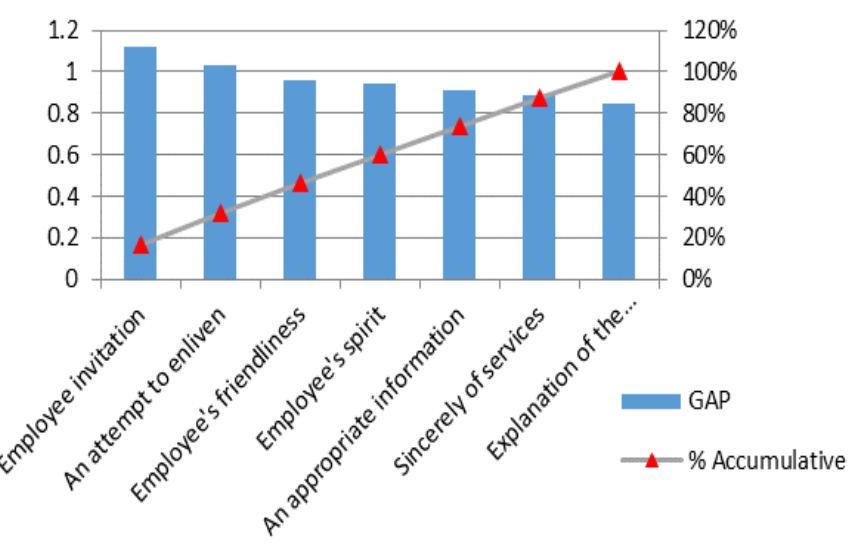

Fig. 6. Pareto Analysis of Brand as A Person

Pareto chart above shows that, the Jungleland's employee invitation to visitors, will have an impact of $17 \%$ on the overall gap exists. The next gap is "an attempt to enliven", it can complete $32 \%$ of the total gap exists.

\section{Brand Identity Comparison with Competitors}

The analysis of the competitor's brand identity Jungleland aims to know the general picture of Jungleland position compared to the competitors. Brand delivered to the visitor will shape perceptions the visitors itself. Each theme park has an identity distinguishes each with competitors. The identity makes visitors have different perceptions of each other theme park.

Jungleland is included as a new comer in the themepark industries compared with its competitors like Dufan, TSI, and TSB but it has opportunity to take a larger market.

In the next matrix, Jungleland shows the position of a strong brand identity that is not according to the perceptions of visitors. It is because the value positioning statement, brand promise, and brand essence are under 3,00. The brand personality or descriptions desired by the people of Jungleland consists of: Seru (Fun), Aman (Safe), Nyaman (Comfortable), Hutan (Forest), Fantasi (Fantasy), Penuh Kejutan (Full of Surprises) yet high perceived by visitors. 


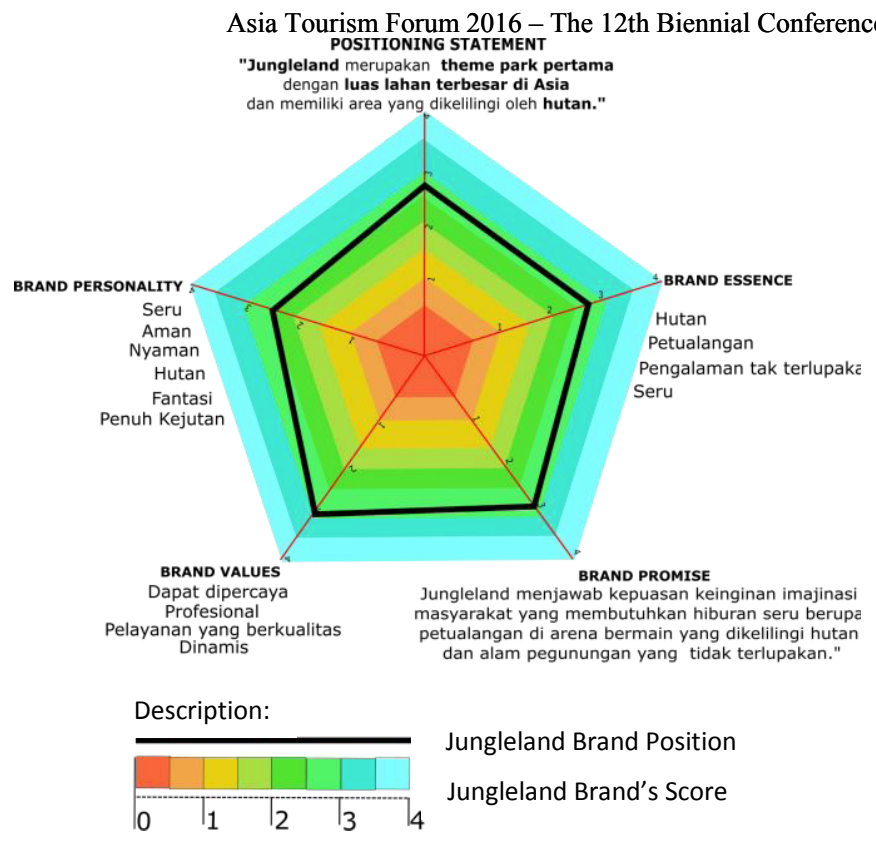

Fig. 7. Brand Identity Jungleland Matrix

Brand values are the values contained in a brand and a quality built and maintained by internal performance in Jungleland mainly through the frontliners. In the next matrix Jungleland's brand values are attributes of the brand identity perceived well by the visitors. It shows that the development of quality human resources is a Jungleland's priority in increasing Jungleland's brand identity on the minds of visitors.

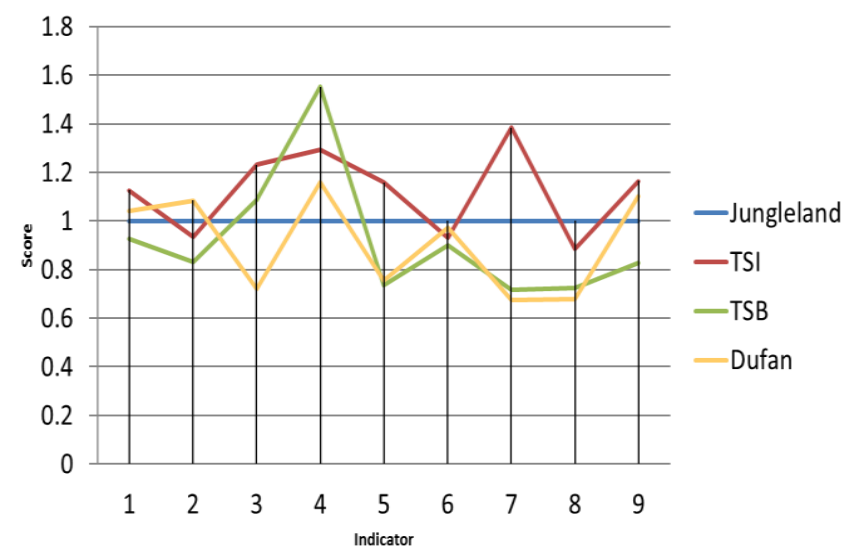

Fig. 8. Brand Identity Comparison with Competitors

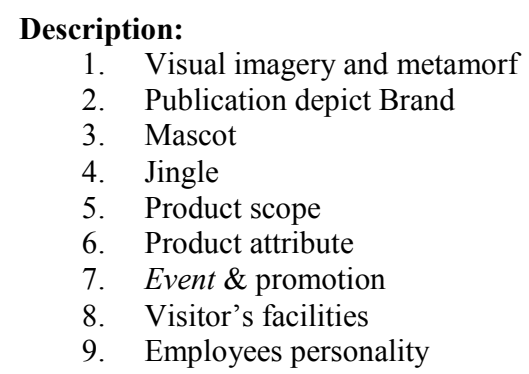

The higher the position of the curve (above 1) the more superior on Jungleland brand attributes of Hospitality and Tourism Industry in Asia (ATF-16)
than competitors and vice versa. From the above graphic, Jungleland compared TSI advantage of all the attributes are in terms of events and promos, Jungleland 0,38 ahead of the TSI. So Jungleland manages to deliver the brand through events and promos offered to visitors. When compared to the TSB and Dufan, Jungleland's advantage of all attributes is a brand through the delivery of superior jingle of 0,55 and 0,16 of the TSB of Dufan.

From all existing attributes, Jungleland's weakness compared to TSI, and Dufan obviously from the delivery of the brand through the existing facilities at the theme park. Jungleland is 0,12 lower than TSI and 0,32 of Dufan. And when it is compared with TSB, Jungleland's weaknesses are from the attributes of the delivery of the brand through events and promos, Jungleland is 0,28 lower thanTSB. Event and promos offered by TSB are still much more to convey the brand compared to Jungleland.

\section{CONCLUSION}

There is a gap among brand identities in customer's perspectives and the organization. The gap is from the brand internalization through top level management and the frontliner. Therefore, based on this research framework two programs are needed to establish the brand based organization in Jungleland Adventure Theme Park: Talent Management Program and Reward Management Program. The programs designed to improve four main aspects: attitude, skill, knowledge and Jungleland brand identity. Talent Management program has an initiative program such as Action Learning, Buzz Program, and Employee Mentoring. Reward Management has an initiative program, Reward, achievement and Most Valuable Employee.

\section{REFERENCES}

[1] Marr, B. \& Jonathan Chatzkel. 2004. Intellectual Capital At The Crossroads: Managing, Measuring, And Reporting Of IC: Journal Of Intellectual Capital.

[2] Preffer, J. 1994. Competitive Advantage Through People: Unleashing The Power of The Workforce. Boston, Mass., Harvard Business School Press.

[3] Harris, Fiona and De Chernatony, Leslie. 2001. Corporate Branding and Corporate Brand Performance. European Journal of Marketing. 